\title{
Economic Development Resiliency: Mobilized Disaster's Readiness Among Higher Learning Students in Malaysia
}

\author{
Nurhanie Mahjom ${ }^{1}$, Azila Abd Razak ${ }^{1}$, Fidlizan Muhammad ${ }^{1}$, Mohd Yahya Mohd Hussin ${ }^{1} \&$ Siti Salma Syahierah \\ binti Mansor ${ }^{1}$ \\ ${ }^{1}$ Universiti Pendidikan Sultan Idris, Tanjung Malim, Malaysia \\ Correspondence: Nurhanie Mahjom, Universiti Pendidikan Sultan Idris, Tanjung Malim, Perak, Malaysia. E-mail: \\ nurhanie@fpe.upsi.edu.my
}

Received: October 10, 2019

Accepted: November 5, 2019

Online Published: December 23, 2019

doi:10.5430/rwe.v10n5p81

URL: https://doi.org/10.5430/rwe.v10n5p81

\begin{abstract}
Resilient economic development is supported by each and every people as a whole. To deal with disasters, we should not act alone. Readiness is one part of the process of disaster management and natural disasters that disrupt the living system. The study was conducted to measure the level of readiness for emergencies and disasters among youth (eg: high learning students) and to develop items for factors that influence students' ability to serve in disaster areas. To achieve the following objectives, two analyses were conducted: the first analysis was the comparison of mean scores and the second analysis was the factor analysis involving four factors, physical factors, university management factors, financial factors and personal factors. This study uses questionnaire and online form to collect data from respondents. A total of 120 respondents from three higher learning in Malaysia - Universiti Pendidikan Sultan Idris (UPSI), Universiti Sains Malaysia (USM) and University of Technology (UiTM) were involved in this study. The level of readiness has a high mean value and indicates a good level of readiness among the respondents. Factor analysis showed that there were no significant differences between the techniques of determining the number of factors or not for all the items that were formed. Nevertheless, the Cronbach Alpha values indicate that the items are constructed and that the overall research tool has internal consistency values. This study is expected to increase the engagement and spirit of volunteerism as it can add value to the students and even produce a high quality national leadership.
\end{abstract}

Keywords: economic development, readiness, disaster, youth, Malaysia

\section{Introduction}

Economic development is not just focusing on the increasing of Gross Domestic Product (GDP) per se, but it is a multi-dimensional concept that takes into account the changes and effects of government action on managing the country. A resilient country has the support of every layer of society with the specific role to plays. One of the youth (eg: students in higher learning) roles' is to engage in volunteer activities (Mark, 2008) for example during natural disaster (Aziz, Sumantoro, \& Maria, 2019).

Currently in Malaysia we are being inundated with sad and shocking news in the newspapers about the occurrence of disasters (either man-made or natural disasters). This sadness is being shared together with other readers all over the world. Natural disasters have indeed caused many innocent deaths. This phenomenon happens in the form of landslides, flash floods, haze, tsunamis, earthquakes and volcanic eruptions (Ibrahim Komo, 2010; Negrut, 2017). However, there is no clear solution for stopping these natural disasters from happening. This is because it is common understanding that when the time comes, these natural disasters would surely occur. No one can actually compete with the forces of nature, but natural disasters caused by human behavior can still be given attention so that human life is not threatened (Basri, 2019).

One such human behaviour which causes natural disasters is logging. This activity contributes towards the country's economy but it can also cause natural disasters (Cruz, 2005). Additionally, there are some irresponsible community members who dispose litter and rubbish into the drains and rivers indiscriminately. This causes the drainage system to be clogged with the rubbish. This is made worse due to the unplanned development on the hillsides (Ibrahim Komo, 2010). This would certainly cause an unstable condition and further result in landslides. As an example, 14 bungalows were destroyed by a landslide and 4 people lost their lives on 6 December 2008 (Utusan Online, 2008). 
Thankfully, there are voluntary associations which are attentive towards such issues. These parties call for assistance from youths (especially university students) to help them in such a mission. For example, the 2014 flood in Kelantan caused Malaysians to sympathise with the plight of the victims and many university students took part in the disaster relief mission. When a student takes part in such an activity, he or she would develop sympathetic feelings and a helpful nature towards humankind. There are indeed many benefits and advantages to be acquired from voluntary work without expecting huge or luxurious rewards.

Sources indicated that there was an increase in the number of volunteers among the students; however, not many were willing to sacrifice their time and energy to help the victims of natural disasters (Alias \& Balakrishnan, 2017). Many would rather give excuses such as having to complete assignments or returning to their villages (Suanda et. al, 2012; Swenson, 2016). As such, this study was conducted to ascertain the extent of the students' willingness to be mobilized again if such a disaster happened in the future.

Unexpected disasters can cause a huge impact towards the surroundings as the community may not be prepared to face such a calamity. Usually after a disaster occurs, the victims have to face a considerable loss. This in turn will cause the victims to become traumatized and depressed to clean up their damaged homes. As such, the responsible parties have to play their roles in helping the disaster victims. These parties include the fire brigade, the civil defence, NGOS, voluntary members (undergraduates) and a few others.

A helpful nature is the basis for harmony and unity in the Malay community (Julianawati et. al, 2012). Such an activity which is based on helping one another and 'gotong royong' has been in the Malay community for generations. This positive value should be preserved in the Malaysian community. Many students nowadays are becoming aware of the need to provide voluntary service in their daily lives. This is because there are many benefits which could be acquired daily without expecting any rewards.

When a student is involved in a voluntary activity, he or she would develop sympathy and a helpful nature towards other people. This positive value should be in every student so that he or she can excel academically as well as become a holistic and brilliant human capital (Julinawati Suanda et. al, 2012). According to Marta and Pozzi (2008) in the study by Julinawati Suanda et. al (2012), they stated that in more recent years, the involvement of youths, specifically students, had increased in voluntary activities.

However, as stated by Azizan Bahari (2009), some students of Malaysian public universities seemed to dislike such voluntary activities. This is because they might have their own activities during the weekend or the mid-term semester break. As such, this may cause the students to be less prepared and lack experience if they were mobilized to help disaster victims. Based on three selected Malaysian public universities which are Universiti Pendidikan Sultan Idris (UPSI), Universiti Sains Malaysia (USM) and Universiti Teknologi Mara (UiTM) Shah Alam, the researcher sought to identify the level of readiness in facing a disaster among the students of Malaysian public universities and the factors which influenced them to be mobilized to disaster areas.

\section{Literature Review}

According to dictionary, disaster carries a certain meaning which is something which causes misery, loss or suffering. As for natural disaster, this is a disaster caused by changes in nature (Poerwadarminta, 2006; Okechukwu, \& Hyginus, 2017). According to Undang-Undang No.24 for 2007, disaster is an occurrence or a chain of events which threaten or interfere with people's lives or well-being which can be caused by natural factors or non-natural factors such as the human factor, and would result in the loss of human lives, environmental damage, loss of wealth and psychological effects. Disasters are a combination of three elements, which are the threat of disaster, vulnerability, and the force triggered by the incident.

Natural disasters are disasters caused by events or a chain of events started by natural occurrences with effects such as environmental damage, loss of goods as well as accidents which could result in the loss of human lives (Kamadhis UGM, 2007).

According to Carter (1991) in LIPI-UNESCO/ISDR (2006), readiness consists of actions which would enable the governments, organizations, societies, and individuals to consider a disaster situation in a fast and accurate way. The steps would include disaster preparedness planning, resource management and individual training. Readiness comprises activities focused on developing plans to respond to disasters quickly and effectively.

Readiness is an element of disaster management process specifically involving natural disasters as it is an important element of proactive disaster risk reduction management activities, before the actual disaster occurs. the disaster. The readiness concept is focused more on the ability to take emergency action in a timely and timely manner (LIPI-UNESCO/ISDR, 2006). 
Readiness requires good preparation by considering multiple actions for minimizing any losses caused by the disaster, as well as making plans so that effective assistance and treatment could be given when the disaster occurs (Japanese Red Cross Society, 2009).

Mobilisation is a person's ability to move independently, easily and in an orderly manner for the purpose of fulfilling the needs of a healthy life. It is a necessary step to increase health, to delay the after effects of disasters such as degenerative diseases and for actualization (Mubarak, 2008).

\section{Research Metodology}

The methodology utilized in a particular study is important as it plays a role in acquiring reliable and valid findings. To acquire reliable and valid findings, the methodology has to be the aspect of primary importance. This is to ensure that the methodology utilized by the researcher has fulfilled the study aims. The research methodology provides a guide in implementing the study (Azizi Yahya et. al, 2009; Bessie et. al., 2016). This section would discuss the research design, study population and sample, study instruments, data collection procedure and data analysis.

This study was conducted on 120 students chosen through a snowball sampling from 3 Malaysia public universities: USM, UPSI dan UiTM Shah Alam. The respondents studied at different universities and had different demographic factors. To assess the study validity, a reliability test towards the questionnaire items were conducted. The purpose of the test is to assess the reliability of the study instruments or the survey which was conducted randomly.

According to Hair et. al (2006), the reliability acceptance level for a study instrument showed that the respondent could answer a question or a statement consistently. The authors provided further guidelines about the alpha value which explained the strength of the relationship in Table 2 below:

Table 1. The Alpha value and its strength

Source: Hair et. al (2006)

\begin{tabular}{ll}
\hline Alpha value & Level \\
\hline$<0.6$ & Weak \\
$0.6<0.7$ & Average \\
$0.7<0.8$ & Good \\
$0.8<0.9$ & Very good \\
0.9 & Excellent \\
\hline
\end{tabular}

The reliability value is generally used to assess whether the questionnaire is reliable for measuring the factors in the study. The analysis of the findings shows the number of questions in the questionnaires which are conducted in a relevant manner or generally speaking, if the study instrument has internal consistency values.

The population number for this study would be students who had participated in any voluntary activity organized by the respective universities. As such, the sample selection method for this study was the snowball sampling. This refers to the process of acquiring a small number of samples before the number is increased by the name and location of other samples provided by the original samples. This is almost similar to the process of a snowball rolling downhill as the snowball gets bigger when it gets to the bottom (Rohana Yusof, 2004). The researcher also analysed the instrument reliability by using the Alpha Cronbach analysis to ensure that the instrument or tool was reliable. The set of questions utilised in this study comprised three sections such as the one below:

The questionnaire was divided into three sections:

Section A: Demographic factors

Section B: Readiness level

Section C: Factors Affecting Mobilization

The method used was suitable for assessing the extent of the students' readiness to be mobilized during a disaster situation in Malaysia. The questionnaire construction for sections B and C had been adapted from a study by Maznieda \& Nurhanie (2015); Yildirim et. al (2016). 
The data acquired from the questionnaire was analysed with the SPSS software to acquire the score values and to compare the mean values according to the levels stipulated. The researcher used the mean score interpretation as the mean score presented by Majid (2000) as a reference.

Table 2. Mean score value

\begin{tabular}{ll}
\hline Mean score value & Level \\
\hline $1.00-2.33$ & Low \\
$2.34-3.66$ & Medium \\
$3.67-5.00$ & High \\
\hline
\end{tabular}

The mean score analysis was used to achieve the research's first objective which was to measure the university students' readiness level to face emergencies and disasters. Based on the mean scores acquired, the researcher was able to identify the university students' level of readiness in facing a disaster or emergency event.

The second analysis was the factor analysis. This involved the technique of compiling many items into different factors or constructs. If the researcher wanted to build a reliable test, the factor analysis was one extended way to identify whether the items analysed could direct towards the same construct. Additionally, the factor analysis could be utilised to identify the main factor measured against a statement (Chua Yan Piaw, 2009). Many researchers have utilised the factor analysis to identify, organise or modify certain measurement tools or instruments into specific constructs.

In order to carry out the factor analysis, there are several conditions that need to be taken into account by the researcher. These include the measurement scale, sample size and number of questionnaires. The Likert Scale is an appropriate measurement scale as it is an ordinal scale of 1 to 5 (Chua Yan Piaw, 2009). In addition, the sample size requirement should be100 respondents and above as a large sample size is required in order to conduct the factor analysis.

In the factor analysis, the researchers would look at the value of KMO, which is a measure of data feasibility (Nasuha, 2014). According to Kaiser and Rice (1974), the criterion for measuring KMO values is that a value greater than 0.9 is very good, 0.8 is good, 0.7 is good, 0.6 is weak, 0.5 is weak and under 0.5 is not acceptable (Sharma, 1996)

If the KMO value exceeds 0.6 or the value approaches 1.0 , it can be followed by the factor analysis. If the Barlett's test of sphericity is significant $(\mathrm{p}<0.000)$, this indicates that the data are acceptable for factor analysis. According to Hair et. al (2006), for the factor loading, the average cut-off value is 0.5 . Therefore, items with values greater than 0.5 in the column can be grouped as factors. This is possible based on the assumption that each constructed item has a correlation strength between different items. As such, items with high correlation will be assigned a specific construct because they measure the same concept (Chua, 2009).

\section{Study Findings}

First analysis: Mean score value

Table 3. Descriptive statistics $(\mathrm{N}=120)$

\begin{tabular}{ccc}
\hline Item & Questions & Mean \\
B1a & Talk & .85 \\
B1b & Table top & .12 \\
B1c & Exercise (simulation) & .66 \\
B1d & Others & .02 \\
\hline B2a & 5 days & 3.83 \\
B2b & 7 days & 4.16 \\
B2c & 10 days & 2.95 \\
B2d & 14 days & 2.88 \\
\hline
\end{tabular}




\begin{tabular}{|c|c|c|}
\hline B3a & Drop in academic grades & 2.05 \\
\hline B3b & No free time & 2.34 \\
\hline B3c & $\begin{array}{l}\text { Could not return to the village during the break as } \\
\text { had to be on duty immediately in }\end{array}$ & 3.42 \\
\hline B4a & 24-72 hours earlier & 4.07 \\
\hline $\mathrm{B} 4 \mathrm{~b}$ & Pre-disaster instructions & 4.28 \\
\hline B5a & Method during disaster & 4.58 \\
\hline $\mathrm{B} 5 \mathrm{~b}$ & Method and location during disaster & 4.57 \\
\hline $\mathrm{B} 5 \mathrm{c}$ & Cleansing during disaster & 4.61 \\
\hline B5d & Bathing during disaster & 4.43 \\
\hline
\end{tabular}

Table 3 above shows the level of readiness of IPTA students in certain aspects. Based on the questions given, it shows that eight items with high mean values of 'five days' and 'seven days' were appropriate for the help missions with mean values of 3.83 and 4.16 respectively. This indicates that a week's duration was a good period of time for students to take part in a relief mission. For question number four on how the instructions were issued, this also had a mean value of 4.07 for instructions 'within $24-72$ hours' and 4.28 for 'pre-disaster instructions'. This shows that students need to be instructed in advance of a disaster so that they can help disaster victims more easily.

Question 5 also had a large mean value. This question is about the education and training modules that cover religious aspects. The four items listed are important for the purpose of taking care of themselves while carrying out a relief effort. All the mean values for these questions were high as 4.58 for 'method during disaster ', 4.57 for 'method and location during disaster', 4.61 for 'cleansing during disaster' and lastly 'bathing during disaster' with mean value of 4.43. Among these, it can be seen that the method of cleaning during emergencies is very important and is characterized by the highest mean values. As you know, cleansing is very important as it influences the prayers of a Muslim. Islam places an importance on cleanliness.

Four items had average mean values of 2.34 to 3.66 which corresponded to the time period appropriate for mobilization. It was found that ' 10 days' and '14 days' had mean values of 2.95 and 2.88 , respectively. Further questions about the negative effects on students when mobilized also provided a mean value of 2.34 for 'free time' and 3.42 for 'could not return to the village during the break as had to be on duty immediately in 24-72 hours earlier'.

Therefore, it can be concluded for the respondents that the level of their readiness to volunteer as a disaster relief aid in the country was generally high depending on how the organizers organize the aspects of management and take care of the volunteers.

Second analysis: Factor analysis

Table 4. Table of summary of factor analysis findings

\begin{tabular}{|c|c|c|c|c|c|c|c|}
\hline \multicolumn{4}{|c|}{ OPEN FACTORS } & \multicolumn{4}{|c|}{ FIXED FACTORS } \\
\hline Factor & Item & $\mathbf{C A}_{0}$ & $\begin{array}{l}\text { Number } \\
\text { of items } \\
\text { accepted }\end{array}$ & Factor & Item & $\mathbf{C A}_{0}$ & $\begin{array}{l}\text { Number } \\
\text { of items } \\
\text { accepted }\end{array}$ \\
\hline Internal factor & $\begin{array}{l}\text { CDa - CDf, } \\
\text { C6d - C6f, } \\
\text { C7j - C7n }\end{array}$ & 0.969 & 14 & Internal factor & $\begin{array}{l}\text { CDa - CDf, } \\
\text { C6a, C6d, } \\
\text { C6e, C6f, } \\
\text { C7j - C7n }\end{array}$ & 0.969 & 15 \\
\hline $\begin{array}{l}\text { Knowledge } \\
\text { factor }\end{array}$ & $\begin{array}{l}\mathrm{C} 7 \mathrm{~b}-\mathrm{C} 7 \mathrm{i}, \\
\mathrm{CWb}\end{array}$ & 0.871 & 9 & $\begin{array}{l}\text { Knowledge } \\
\text { factor }\end{array}$ & $\begin{array}{l}\mathrm{C} 7 \mathrm{~b}-\mathrm{C} 7 \mathrm{i}, \\
\mathrm{CWb}-\mathrm{CWd}\end{array}$ & 0.893 & 11 \\
\hline
\end{tabular}




\begin{tabular}{llllllllll}
\hline Action factor & $\begin{array}{l}\text { C6a, C6g, } \\
\text { C6h, C7a }\end{array}$ & 0.841 & 4 & $\begin{array}{l}\text { Communicatio } \\
\text { ndevice factor }\end{array}$ & $\begin{array}{l}\text { C6b, } \\
\text { C7o }\end{array}$ & C6c, 0.771 & 3 \\
\hline $\begin{array}{l}\text { Communicatio } \\
\text { n device factor }\end{array}$ & C6b, C6c, & 0.730 & 3 & Action factor & C6g, C6h & 0.833 & 2 \\
\hline Reward factor & CWc, CWd & 0.903 & 2 & & & & & & \\
\hline $\begin{array}{l}\text { KMO and } \\
\text { Barlett's test }\end{array}$ & $\mathbf{0 . 6 2 4}$ & $\mathbf{0 . 8 6 2 8}$ & $\mathbf{3 1}$ & $\begin{array}{l}\text { KMO and } \\
\text { Barlett's test }\end{array}$ & $\mathbf{0 . 6 2 4}$ & & $\mathbf{0 . 8 6 6 5}$ & $\mathbf{3 2}$ \\
\hline
\end{tabular}

Based on the summary table of the above factor analysis results, it can be concluded that there were two main techniques involved in factor analysis by determining the number of factors and open factors (that is, not specifying the number of factors). From the table it was found that the open factor technique provided five factors: internal factors, knowledge factor, action factor, communication tool factor and reward factor. On the other hand, the fixed factors were determined by four factors: internal factors, knowledge factors, communication tools and action factors.

For the open factors, the total number of items accepted for internal factors were 14 and the Alpha Cronbach value was 0.969 . The knowledge factor had nine items accepted and the Alpha Cronbach value was 0.871 . The action factor had four received items and the Alpha Cronbach value was 0.841 . For the communication device factor, there were three items accepted and the value of Alpha Cronbach was 0.730. Finally, for the reward factor there were two items accepted and the value of Alpha Cronbach was 0.903. All five of these factors also had high Alpha Cronbach values. The items created could be used as questions for these factors as they could best describe what needed to be measured by factors influencing the students' willingness to be mobilized in the event of a disaster

For the number of fixed factors, 15 items representing internal factors were accepted and the Alpha Cronbach value was 0.969. The knowledge factor had 11 items and the value of Alpha Cronbach was 0.893. The communication device factor with the Alpha Cronbach value of 0.771 had three items and the last factor had two accepted items and the Alpha Cronbach value was 0.833. All four factors had high Alpha Cronbach values. This indicates that all the items for each factor could best describe the need for those factors in studying the students' willingness to be mobilized in the event of a disaster.

The KMO and Barlett's test values were the same for both fixed and independent factors at 0.624 . According to Hair, et. al., (2010), these items were eligible for factor analysis when the KMO-MSA value exceeded 0.50 and had significant value. Factor analysis successfully reduces the number of original items to a specific factor. However, according to a study by Majid (2004), the Alpha Cronbach's reliability value can be classified into three classes, and if the Alpha Cronbach's value is 0.60 , it indicates that the reliability index is at least acceptable.

Generally, there was no clear difference between the technique of determining the number of factors for otherwise for all the items that had been formed. The Alpha Cronbach mean values for the open factor and the fixed factors were 0.8628 and 0.8665 respectively.

\section{Conclusion}

Based on the study conducted, the researcher found that some suggestions for improvement for future studies by increasing the sample size. This study was conducted at 3 universities: UPSI, USM and UiTM Shah Alam. The respondents involved were 120 people. For future studies, it was suggested that the number of respondents should be increased or that more public universities in Malaysia should be included. It would not be a problem if students from private universities were also included in order that the study could be expanded and this could perhaps result in better and more reliable findings.

Additionally, future researchers could increase the number of demographic factors. The current study only looked at 5 demographic factors which were the university's name, gender, age, ethnic group and marital status. This study could be further expanded by considering other demographic factors such as semester of study and the faculty's name. Other variables like factors which influenced the students' willingness to be mobilised could also be considered in order to acquire wider and more accurate findings about the students' readiness. Furthermore, the study instrument could be diversified. In this study, the researcher utilised the study instrument such as the questionnaires to the respondents. However, other instruments could be utilised as well such as interview, general observation and experiments so that the findings could be strengthened and not just depend on the findings acquired via the questionnaires. 
Based on the study conducted, it was found that youths like students of public universities in Malaysia had a tendency to take part in voluntary activities. The researcher would like to suggest that the university administration to play an important role in in increasing the students' involvement. For example, the voluntary elements in education could be developed holistically so that students could be exposed to voluntary philosophy and characteristics continuously. It was also suggested that future studies could look at increasing the sample size, increasing the number of demographic factors as well as diversifying the study instruments. The researcher hoped that the study could become a reference for other researchers on the same topic.

\section{References}

Alias, A., \& Balakrishnan, V. (2017). Impak kesukarelawanan dalam kalangan belia di Kuala Lumpur: Satu kajian. JuPiDi: Jurnal Kepimpinan Pendidikan, 3(4), 25-43. Retrieved from https://ejournal.um.edu.my/index.php/JUPIDI/article/view/8443

Aziz, A.R., Sumantoro, I.B., \& Maria, D. (2019). Total Quality Management of micro, small and medium enterprises (MSMES), and the impact to organizational culture and performance: emerging country case. Polish Journal of Management Studies, 19(1), 32-45.

Azizan Bahari. (2009). Kerja Sukarela Kurang Mendapat Sambutan. Artikel Sukarelawan Malaysia. Diperoleh pada Mac 20, 2017.

Azizi Yahya, Shahrin Hashim, Jamaludin Ramli, Yusof Boon, \& Abdul Rahim Hamdan. (2009). Menguasai Penyelidikan dalam Pendidikan: Teori, Analisis dan Intrepretasi Data. Kuala Lumpur: PTS Professional Publishing Sdn. Bhd.

Badan Nasional Penaggulangan Bencana. (2010). Materi presentasi BNPB (Badan NasionalPenanggulangan Bencana) yang disampaikan dalam Pelatihan Dasar Penanggulangan Bencana. Jakarta: Kementrian Lingkungan Hidup.

Basri, W. (2019). Management concerns for social media usage: moderating role of trust in Saudi communication sector. Polish Journal of Management Studies, 19.

Bessie, S., Beyene, F., Hundie, B., Goshu, D., \& Mulatu, Y. (2016). Land use/land cover change and its effects on bamboo forest in benishangul gumuz region, Ethiopia. International Journal of Sustainable Development \& World Policy, 5(1), 1-11.

Chua, Y.P. (2009). Statistik Penyelidikan Lanjutan (Buku 5): Ujian Regresi, Analisis Faktor dan Analisis SEM. Shah Alam: Mc Graw. Hill Education.

Cruz, R. V.O. (2005). Could forests stop floods?. The case of Tignoan and Agos watersheds in Quezon and Dingalan watershed in Aurora, Philippines. Paper presented at the Forestry Development Forum, 2-3 June 2005 Manila: Asian Development Bank.

Hair, J.F., Anderson, R.E., Tatham, R.L., \& dan Black, W.C. (2010). Multivariate data analysis (7th ed.). New York: Prentice Hall International Inc.

Ibrahim Komo. (2010). Manusia Ubah Tabii Alam Punca Berlaku Bencana. Utusan Malaysia.

Japanese Red Cross Society. (2009).

Julinawati S. et al.. (2012). Semangat Kesukarelawan Dalam Kalangan Mahasiswa Melayu Di IPTA: Satu Tinjauan Ke Arah Pembentukan Pendidikan Kesukarelawan. Seminar Pendidikan Melayu Antarabangsa (SePMA) 2012.

Kamadhis UGM. (2007). Eka-Citta Bersatu dalam Dharma, Buletin Kamadhis UGM Nomor.XXVII/September/2007, Yogyakarta: Kamadhis UGM, 2007.

LIPI - UNESCO/ISDR. (2006). Kajian Kesiapsiagaan Masyarakat dalam Mengantisipasi Bencana Gempa Bumi \& Tsunami, Deputi Ilmu Pengetahuan Kebumian Lembaga Ilmu Pengetahuan Indonesia, Jakarta.

Mao, W., \& Jiang, Y. (2015). On the development strategies of the new energy car industry in China. Journal of Asian Business Strategy, 5(5), 80-89.

Mark, A.B. (2008). Conceptualizing Resiliency: An Interactional Perspective for Community and Youth Development. Child Care in Practice, 14(1), 55-64. https://doi.org/10.1080/13575270701733732

Marta, E., \& Pozzi, M. (2008). Young people and volunteerism: A model of sustained volunteerism during the transition to adulthood. J. Adult Dev., 15, 35-46. https://doi.org/10.1007/s10804-007-9033-4 
Maznieda, M., \& Nurhanie, M. (2015). Health Care Workers Mobilization of MOH during massive flood: A case study. Proceeding of $11^{\text {th }}$ MOH-AMM Scientific Meeting incorporating the $18^{\text {th }}$ NIH Scientific and Annual National Ethics Seminar, Institute for Health Management, Kuala Lumpur.

Mohd, M.K. (2000). Kaedah penyelidikan pendidikan. Edisi Ke-5. Kuala Lumpur: Dewan Bahasa \& Pustaka.

Mubarak, H. (2008). Original Article "Acute Appendicitis" from Harrison's Principle of Internal Medicine 17th Ed. Retrieved from http://cetrione.blogspot.com/

Mulyana, B., Daryanto, A., \& Purwito, A. (2018). Business Model Development Strategy of Padjadjaran University with Canvas Business Model Approach. Asian Business Research Journal, 3, 1-8.

Nasuha, M. (2014). Analisis Tahap Pengetahuan Pembayar Zakat Mengenai Kepelbagaian Faktor Pemilihan Kaedah Pembayaran Zakat di Hulu Selangor. Perak: Universiti Pendidikan Sultan Idris.

Negrut, V. (2017). Overview of the Most Common Types of Maladministration Raised at EU Level. International Journal of Public Policy and Administration Research, 4(2), 35-40.

Okechukwu, O.C., \& Hyginus, O.O. (2017). National Security and Democratization in Nigeria: The Case of Insurgence. International Journal of Public Policy and Administration Research, 4(1), 12-18.

Pisi, B.A. (2019). Education Model for Environmental Living Environment Based on Local Genius for Elementary School Students Who Lived in Peatland. American Journal of Social Sciences and Humanities, 4(3), 461-473.

Poerwadarminta, W.J.S. (2006). Kamus Besar Bahasa Indonesia. Jakarta: Balai Pustaka.

Rohana, Y. (2004). Penyelidikan sains sosial (Edisi Kemas Kini). Pahang: PTS Publications \& Distributors Sdn Bhd.

Saileshsingh Gunessee, Nachiappan Subramanian, Samuel Roscoe, \& Jothibasu Ramanathan. (2018). The social preferences of local citizens and spontaneous volunteerism during disaster relief operations. International Journal of Production Research, 56(21), 6793-6808, https://doi.org/10.1080/00207543.2017.1414330

Sharma, A. (1996). The Effect of Priming Cues in Sales Interactions: Additional Perspectives. Journal of Personal Selling and Sales Management, 16(2), 49-52.

Swenson, C. (2016). Empirical evidence on municipal tax policy and firm growth. International Journal of Public Policy and Administration Research, 3(1), 1-13.

Utusan Online. (2008). 14 Banglo Tertimbus Tanah Runtuh di Bukit Antarabangsa. Diperoleh pada Feb 26, 2017. Dimuat turun daripada. Retrieved from http://ww1.utusan.com.my/utusan/info.asp?y=2008\&dt=1206\&sec=Terkini\&pg=bt_01.htm

Wan Mohd Noor Hafiz Wan Mansor. (2017). Tugas sukarela tidak pilih kaum, agama. Sinar Online.

Yildirim, U., Soner, A.K.I.N., Gül, Z., \& Çiçek, Y. (2016). A Review on EU Transportation Projects within the Case of Turkey for European Union Regional Development Policy. International Journal of Sustainable Development \& World Policy, 5(1), 12-25. 